\title{
Changes in water chemistry along the newly formed High Arctic fluvial-lacustrine system of the Brattegg Valley (SW Spitsbergen, Svalbard)
}

\author{
Henryk Marszałek ${ }^{1}$ - Dorota Górniak ${ }^{2}$
}

Received: 30 March 2016/Accepted: 16 June 2017 / Published online: 28 June 2017

(C) The Author(s) 2017. This article is an open access publication

\begin{abstract}
Changes in water chemistry along the High Arctic fluvial-lacustrine system located in Wedel Jarlsberg Land in the SW Spitsbergen (Svalbard) were investigated during the summer season of 2010 and 2011. The newly formed river-lake system consists of three lakes connected with the Brattegg River. The first bathymetric measurements of these lakes were made by the authors in 2010. The Brattegg River catchment represents a partly glaciered Arctic water system. The studied lakes are characterized by low mineralization and temperature of water. The value of the electrolytic conductivity (EC) ranges from 30.2 to $50.5 \mu \mathrm{S} \mathrm{cm}^{-1}$ and the temperature of surface water from 1.5 to $7.8^{\circ} \mathrm{C}$. The temperature increase takes place downstream starting from Upper Lake to the outflow from Myrktjørna Lake. The waters of lakes have higher temperatures than the stream. The predominant ions are $\mathrm{HCO}_{3}{ }^{-}$(up to $16.5 \mathrm{mg} \mathrm{L}^{-1}$ ), $\mathrm{Cl}^{-}\left(6.66-8.53 \mathrm{mg} \mathrm{L}^{-1}\right.$ ), $\mathrm{Ca}^{2+}\left(2.40-4.45 \mathrm{mg} \mathrm{L}^{-1}\right)$ and $\mathrm{Na}^{+}\left(2.65-3.36 \mathrm{mg} \mathrm{L}^{-1}\right)$. The highest values of ammonium and DOC found in the lowest Myrktjørna Lake seem to be related to the presence of aquatic organisms and also birds. From the group of 10 analyzed microelements, increased concentrations of aluminum, up to almost $500 \mu \mathrm{g} \mathrm{L}^{-1}$, are present in the lakes'
\end{abstract}

Henryk Marszałek

henryk.marszalek@uwr.edu.pl

Dorota Górniak

gorniak@uwm.edu.pl

1 Department of Applied Hydrogeology, Institute of Geological Sciences, Wrocław University, M. Borna Sq 9., 50-204 Wrocław, Poland

2 Department of Microbiology, Faculty of Biology and Biotechnology, University of Warmia and Mazury in Olsztyn, Oczapowskiego 1A, 10-957 Olsztyn, Poland water. Water isotopic composition ranges for $\delta^{18} \mathrm{O}$ and $\delta^{2} \mathrm{H}$, from -10.6 to $-10.9 \%$ and from -70.8 to $-72.3 \%$, respectively. The vertical zonality of lake waters is manifested in a decrease in the temperature and increase in EC and chemical elements concentrations.

Keywords Fluvial-lacustrine system · Water chemistry · Spitsbergen

\section{Introduction}

Rapid glacier melting in the Arctic and the other regions of the world has been apparent for several decades. Arctic ecosystems are highly sensitive to global warming, and the air temperature has almost doubled there in the past 100 years compared to the average global increase (Jania and Hagen 1996; Hanssen-Bauer 2002a, b; Bernstein et al. 2007). Recession of the Werenskiold Glacier in the southwestern part of the Spitsbergen is a prime example of ensuing Arctic changes (Fig. 1). Here, recession started at the beginning of the twentieth century and has a current average spread of $25 \mathrm{~m} \mathrm{year}^{-1}$ (Bukowska-Jania 2003). Similar phenomena are observed in the neighboring catchment of the Brattegg River, which is originated in the newly created upper cirque lake and recharged by the small Brattegg mountainous glacier (Fig. 1). It then flows through the middle small lake into the large and oldest Myrktjørna Lake, and at the end to the Nottingham Bay of the Greenland Sea.

Thus, in the Brattegg Valley the three lakes and river combine diverse ecosystem in which water provides a continuous life environment for organisms in both time and space. There is not too much information about the functioning of such systems in polar conditions. Lakes in the 

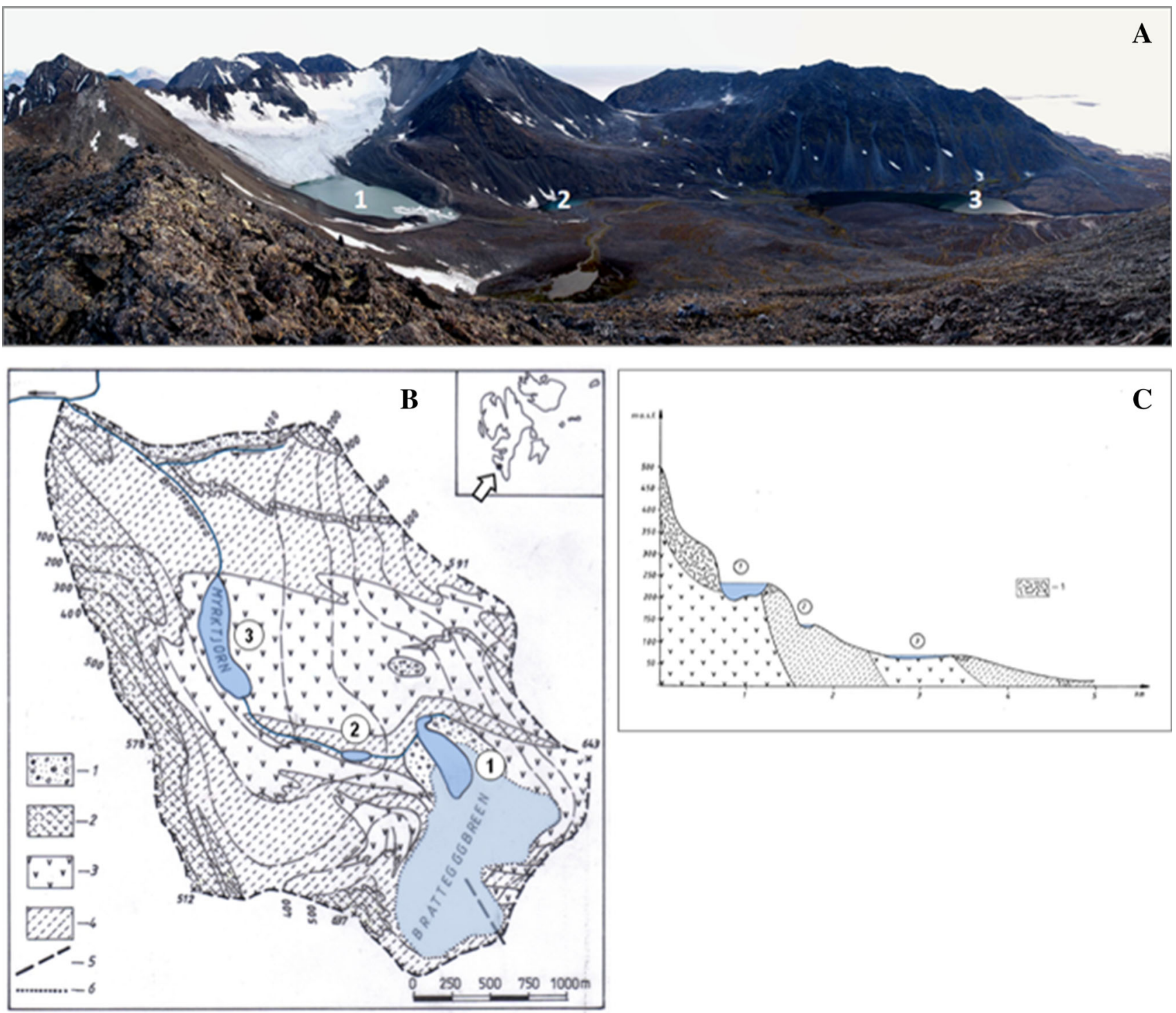

Fig. 1 Brattegg Valley lake-river system: a view from Angelfjellet (fot. M. Kasprzak), b Sketch map of river-lake system in Brattegg catchment on geological background (geology after Manecki et al. 1993): 1 Upper Lake, 2 Middle Lake, 3 Myrktjørna lake, Bratteggbreen-Brattegg glacier. Lithology: 1 moraine deposits (quaternary),

Brattegg Valley create a unique connected polar ecosystem, which enables us to study the ecological succession including changes in microbial communities. The development of specific organism communities is closely related to the specific physicochemical properties of lake waters, resulting from their different altitudes, surface area and depth. The study of both water chemistry and aquatic microbiocenosis, described in Górniak et al. (2016), in such a relatively simple and anthropogenically undisturbed polar environment promotes further knowledge of lake ecosystem functioning.

Field investigations were carried out in the spatial gradient of proglacial and supraglacial aquatic ecosystems
Middle Proterozoic: 2 quartzites, 3 amphibolites, 4 mica-schists with intercalations of amphibolites and metarhyolites, 5 faults, 6 catchment boundary. c Hypsometric position of lakes in the Brattegg River catchment (1 Brattegg glacier, lithology as in Fig. 1b)

formed and transformed by deglaciation. The Brattegg river-lake system, consisting of three lakes connected by a stream, provides excellent progressive succession stages from youngest to oldest. The highest deep cirque lake is supplied with water from the melting Brattegg glacier. It was exhumed from ice over the past few years due to the glacier's rapid recession. Below it, the second flow lake was formed in a small morphological depression at the foot of the Jahnfjellet Mountain. These two upper lakes have not been previously described. The lowest and oldest Myrktjørna reservoir is relatively vast and shallow with well-developed microbial mats and is well populated with fish. 
Over the past several decades, a series of papers describing the water chemistry in the western Svalbard were published. Among the most important, characterizing both surface- and groundwater, are: Bieroński (1977), Krzyszowska (1985), Krawczyk (1992), Haldorsen and Lauritzen (1995), Haldorsen et al. (1996), Pulina et al. (1999), Cooper et al. (2002), Krawczyk et al. (2008), Marszałek and Wasik (2013) and Olichwer et al. (2013). The majority of studies were focused on the chemical composition of different types of waters, including those which occur in the vicinity of the Hornsund region. However, there are no results of chemical research conducted in the Brattegg Valley fluvial-lacustrine system. Despite the unique ecological nature of this system, there is not too much information about its limnochemistry. Therefore, the main aim of this study was to describe the spatial variability of physicochemical parameters and nutrient contents in the Brattegg Valley river-lake system and to explain the mechanism of these chemical changes.

\section{Study area}

The Brattegg River catchment with the area of $8.2 \mathrm{~km}^{2}$ is located in Wedel Jarlsberg Land in the Sør-Spitsbergen National Park (SW Svalbard, unincorporated area administered by Norwegian governor) (Fig. 1). It belongs to a partly glaciered river-lake system composed of three lakes (Upper, Middle and Lower, called Myrktjørna) of different sizes (9.10, 1.30 and $13.6 \mathrm{ha}$ ) and depths (max. 40.3, 6.70 and $6.90 \mathrm{~m}$ ), linked by the Brattegg River (Fig. 1). The orographic borders of the catchment area are formed by the summits of Angellfjellet (590.6 m a.s.1.), Brattegg (645.0 $\mathrm{m}$ a.s.1.), Jahnfjellet (643.0 $\mathrm{m} \mathrm{m}$ a.s.1.) and Gullichsenfjellet (583.0 m m a.s.1.). The Brattegg River is quite a small watercourse draining coastal parts of the western Spitsbergen during the summer Arctic seasons. The length of the river, together with the lakes, is $4 \mathrm{~km}$. Its catchment is distinguished by diverse topography related to the history of this glacial area (Fig. 1). The river flows toward the mouth of the Greenland Sea overcoming a series of threshold rocks to recharge three lakes formed in morphological depressions. This process resulted in a typical Arctic river-lake system close to the Werenskiold glacier. Only $0.37 \mathrm{~km}^{2}$ of area is permanently ice-covered (Marszałek et al. 2013a). The slope of the river is high in its upper part (6\% on average) and decreases below the Myrktjørna Lake outflow.

Geologically, this part of Spitsbergen area is built of Middle Proterozoic metamorphic rocks of several crystalline formations (Birkenmajer 2013). Various rocks including amphibolites, mica-schists, quartzites of the Brattegg Valley formation and white and green quartzites of the Gullichsenfjellet formation occur in the northern part of this region (Manecki et al. 1993). The coastal zone is built of crystalline rocks covered by sands and gravels of marine origin forming an array of terraces and boulder fields, as well as formations of weathering cover with clay fraction admixture. The crystalline bedrock has varying degree of fissuring and weathering in the upper parts of the profile, increasing in depth down the slope (Marszałek and Wassik 2013). The river valleys are filled with coarse clastic material, while the coastal zone is covered with boulders and coarse gravel forming a system of coastal terraces (Fig. 1). Common in this area moraine formations are the results of local glacier activity.

\section{Methods}

The lakes' bathymetry was measured twice using a small rubber boat: firstly, in August 2010 with the use of loaded tape and then repeated in 2011 by Echo Sounder connected to a GPS system. The raw data collection was conducted in 58 of Upper, 16 of Middle and 100 of the Myrktjørna, lakes studied points. The measurements were taken in longitudinal and transverse transects per surface area of lakes. The spatial interpolation using a kriging method (Cressie 1991) was based on spot soundings from 2011 and additional data points from 2010. The calculations were made with the Surfer 7.0 software, and the maps were produced using ARC-GIS 9.0 software.

During bathymetric measurements, water samples were collected for chemical, isotopic and microbiological analysis at the 16 points situated along the Brattegg valley river-lake system (Fig. 1b). The temperature (T), electrolytic conductivity (EC) and $\mathrm{pH}$ of waters were directly measured in the field in three points: at the surface, in the middle and at the bottom of lakes using a calibrated WTW 340 multiparametric meter (WTW GmbH, Xylem Inc. Germany). The precision of measurements was $0.01 \mu \mathrm{S} \mathrm{cm}^{-1}$ for EC and 0.01 for $\mathrm{pH}$. Additionally, tributary and outflow waters were sampled in order to determine the supply routes of reservoirs. Surface water $(\leq 0.25 \mathrm{~m})$ was sampled in the inlets and outlets of lakes. In the deepest points of lakes, water was sampled from the surface, central part of water column and near bottom using a 5-L Niskin bottle. All samples were transferred to sterile acid-washed polyethylene 2-L containers previously rinsed with distilled water and immediately transported to the nearby field laboratory at the Wrocław University "Baranowski" summer research station. The samples were processed or preserved immediately upon return to the field laboratory, maximally $2 \mathrm{~h}$ after sampling. Samples for isotopic analysis were collected into 10-mL glass vials, which were closed with a rubber stopper and an aluminum cap at the time of sampling. 
Alkalinity was measured in the laboratory by colorimetric titration with $\mathrm{HCl}$. Besides the basic ionic composition, also dissolved organic carbon (DOC), nitrogen compounds $\left(\mathrm{NO}_{3}{ }^{-}, \mathrm{NO}_{2}{ }^{-}, \mathrm{NH}_{4}{ }^{+}\right)$and phosphates $\left(\mathrm{PO}_{4}{ }^{3-}\right)$ were determined, as well as such selected microelements as $\mathrm{Mn}$ and $\mathrm{Fe}, \mathrm{Pb}, \mathrm{Cd}, \mathrm{Cu}, \mathrm{Zn}, \mathrm{Al}, \mathrm{Ni}, \mathrm{Cr}, \mathrm{Co}$.

After filtration through $0.45-\mu \mathrm{m}$ pore-sized filters (Millipore HAWP), DOC and total nitrogen (N-tot) contents were determined in a Shimadzu TOCV-CSH organic carbon analyzer with a TNM-1 total nitrogen analyzer attachment. Standards were prepared from reagent grade potassium hydrogen phthalate in Milli-Q Plus Ultra Pure Water. Samples and standards were acidified to $\mathrm{pH} 2$ with $2 \mathrm{M} \mathrm{HCl}$ and purged with free $\mathrm{CO}_{2}$ gas for $5 \mathrm{~min}$ at a flow rate of $125 \mathrm{~mL} \mathrm{~min}^{-1}$ to remove inorganic carbon prior to injection onto a heated catalyst bed $(0.5 \% \mathrm{Pt}$ on alumina support, $680{ }^{\circ} \mathrm{C}$, regular sensitivity). A non-dispersive infrared detector measured carbon dioxide gas from the combusted carbon. Each sample was injected three times. The coefficient of variation (CV) for the repeated analysis was $\leq 2 \%$. Phosphorus and nitrogen form concentrations were measured according to standard methods (1999). The accuracy of measurements for phosphorus was 0.001 and $0.01 \mathrm{mg} \mathrm{L}^{-1}$ for nitrogen. The chemical composition of water including major ions and trace elements was determined using the atomic absorption spectrometry (AAS) method with graphite tray (PerkinElmer GmbH, Germany). Measurements were replicated three times.
Tracer methods were used for the evaluation of the relationships between surface- and groundwater. They were also helpful in determining the origin and age of water. In this study, stable isotopes of oxygen $\left({ }^{18} \mathrm{O}\right)$ and hydrogen $\left({ }^{2} \mathrm{H}\right)$ were used as environmental tracers. Stable isotope ratios of oxygen and hydrogen in the water molecule are expressed as relative deviations from the pattern of isotopic composition similar to the composition of ocean water and given in per mille (\%o), respectively, as $\delta^{18} \mathrm{O}$ and $\delta^{2} \mathrm{H}$.

\section{Results}

The Brattegg River begins in the upper youngest, deep and cold cirque lake, recharged from glacial ablation at the altitude over $234 \mathrm{~m}$ a.s.l. (Fig. 2). At a lower point, it crosses the frontal moraine and forms cascades into the middle smaller lake at $139 \mathrm{~m}$ a.s.l., which flows over detrital massif rocks into the larger and oldest Myrktjørna Lake at $72 \mathrm{~m}$ a.s.l. Through the clearly marked belt of older moraine at $95 \mathrm{~m}$ a.s.l., it flows rapidly into the valley to join outflow from the Werenskiold glacier and falls into the Nottingham Bay of the Greenland Sea.

The three lakes of the Brattegg Valley system are of different sizes and depths (Table 1; Fig. 2). They differ in the morphometric parameters and also in the time of forming. The deepest (up to $40 \mathrm{~m}$ ), upper reservoir (No. 1) is a typical young cirque lake newly formed in front of the

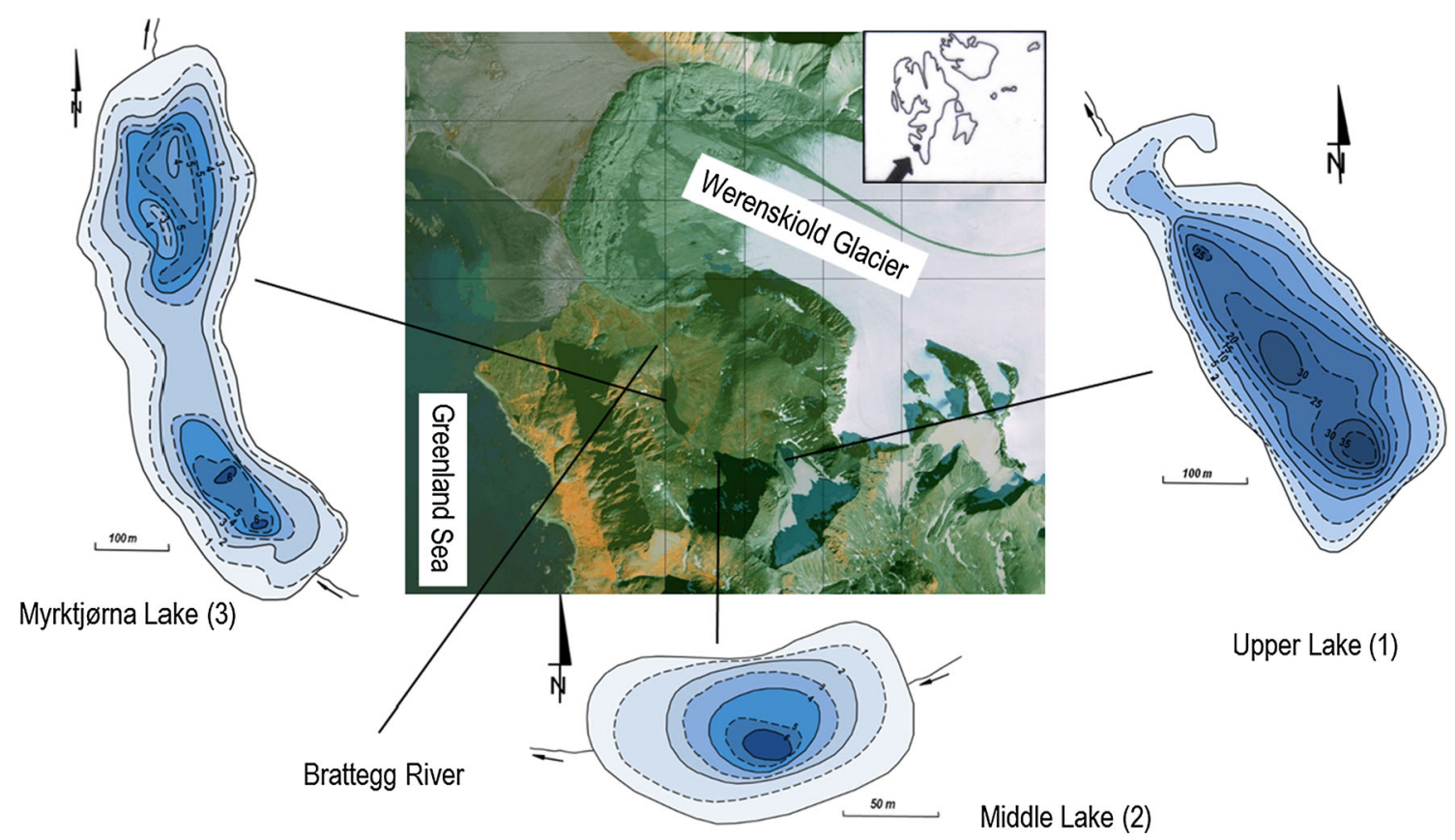

Fig. 2 Location of the Brattegg river-lake system (basemap after Kolondra 1995) with bathymetric maps of studied lakes (depth contours in meters) 
Table 1 Lakes characteristic and selected physicochemical parameters of water column

\begin{tabular}{|c|c|c|c|c|c|c|c|c|}
\hline \multirow[t]{2}{*}{ Lake (no.) } & \multirow[t]{2}{*}{ Location (GPS position) } & \multirow[t]{2}{*}{ Altitude (m a.s.1.) } & \multirow[t]{2}{*}{ Area (ha) } & \multirow{2}{*}{$\begin{array}{l}\text { Depth } \\
\text { Max (m) }\end{array}$} & \multicolumn{4}{|c|}{ Physicochemical parameters of water } \\
\hline & & & & & Depth (m) & Temp. $\left({ }^{\circ} \mathrm{C}\right)$ & $\mathrm{EC}\left(\mu \mathrm{S} \mathrm{\textrm {cm } ^ { - 1 } )}\right.$ & $\overline{\mathrm{pH}}$ \\
\hline \multirow[t]{3}{*}{ Upper (1) } & $77^{\circ} 03^{\prime} 167^{\prime \prime} \mathrm{N}$ & 234 & 9.05 & 40.3 & 0.50 & 1.50 & 30.2 & 6.61 \\
\hline & $15^{\circ} 15^{\prime} 203^{\prime \prime} \mathrm{E}$ & & & & 20.0 & 1.10 & 37.9 & 6.33 \\
\hline & & & & & 35.0 & 1.00 & 38.6 & 6.26 \\
\hline \multirow[t]{3}{*}{ Middle (2) } & $77^{\circ} 03^{\prime} 093^{\prime \prime} \mathrm{N}$ & 139 & 1.28 & 6.70 & 0.50 & 4.90 & 35.4 & 6.47 \\
\hline & $15^{\circ} 14^{\prime} 338^{\prime \prime} \mathrm{E}$ & & & & 3.00 & 4.60 & 30.2 & 6.54 \\
\hline & & & & & 6.00 & 4.50 & 30.5 & 6.75 \\
\hline \multirow[t]{3}{*}{ Myrktjørna (3) } & $77^{\circ} 03^{\prime} 207^{\prime \prime} \mathrm{N}$ & 72 & 13.6 & 6.90 & 0.50 & 7.60 & 50.5 & 6.77 \\
\hline & $15^{\circ} 12^{\prime} 362^{\prime \prime} \mathrm{E}$ & & & & 2.60 & 7.30 & 36.4 & 6.52 \\
\hline & & & & & 5.00 & 7.10 & 35.2 & 6.55 \\
\hline
\end{tabular}

residual Brattegg glacier. The relatively narrow, long at over $0.5 \mathrm{~km}$ and elongated in the direction of NW lake is covered with lake ice during most of the year. The ice cover usually persists until August. It has an area of approximately 9 ha and diverse depth increasing rapidly from the edges (Table 1; Fig. 2). There have been recorded three distinct depressions in the depth profile, from $25 \mathrm{~m}$ to almost $40 \mathrm{~m}$ at the head of the glacier (Fig. 2). It is recharged by melting glacier waters and gives rise to the Brattegg stream. A much smaller area (approximately 1.3 ha) has a middle flow lake (No. 2), partially backfilled with rock material from glacial denudation and erosion in the upper part of the catchment. The maximum depth of $6.7 \mathrm{~m}$ was recorded in the central part of the lake (Table 1; Fig. 2). It is recharged by water of the Brattegg River and small streams from ephemeral springs and from melting snow. A similar depth $(6.9 \mathrm{~m})$ and the way of recharge have the greatest (about 14 ha), lower lake (No. 3) called Myrktjørna (Table 1; Fig. 2). The lake area has an elongated shape in the N-S direction and various depths with two distinct depressions in the south and the north parts of it (Fig. 1). This oldest and much longer reservoir seems to be partly buried by rock material. Its depth is relatively small and reaches almost $7 \mathrm{~m}$ in the southern part (Fig. 2; Table 1). The bathymetric map of the Brattegg river-lake system has been made for the first time (Fig. 2).

The location of the Brattegg River catchment in the polar region influences the low temperature of surface water ranging from 1.5 to $7.8{ }^{\circ} \mathrm{C}$. The temperature increase takes place downstream starting from Upper Lake No. 1 to the outflow from Myrktjørna and further toward the Greenland Sea. The lake waters have higher values of temperature. Stream water, recharged during its flow in valley by cold water from different sources (mainly by surface runoff and subsurface inflow from the active layer of permafrost), has lower values of temperature. The temperature of water changes with the depth of all studied lakes, respectively, from 1.5 to $1.0^{\circ} \mathrm{C}$ in Upper Lake,
4.9-4.1 ${ }^{\circ} \mathrm{C}$ in Middle to $7.6-7.1{ }^{\circ} \mathrm{C}$ in Myrktjørna (Table 1).

The surface waters have very low mineralization and are of slightly acidic $\mathrm{pH}$. The electrolytic conductivity values range from 30.2 to $50.5 \mu \mathrm{S} \mathrm{cm}^{-1}$, and $\mathrm{pH}$ is within 6.26-6.77 (Table 2). The predominant ions are bicarbonates $\mathrm{HCO}_{3}{ }^{-}$(from 12.2 to $18.3 \mathrm{mg} \mathrm{L}^{-1}$ ), chlorides $\mathrm{Cl}^{-}$ (6.66-8.53 mg L $\left.{ }^{-1}\right)$, calcium $\mathrm{Ca}^{2+}\left(2.40-4.45 \mathrm{mg} \mathrm{L}^{-1}\right)$ and natrium $\mathrm{Na}^{+}$, ranging from 2.65 to $3.94 \mathrm{mg} \mathrm{L}^{-1}$ (Table 2). The concentrations of nitrogen compounds are rather low. The amount of $\mathrm{NO}_{3}{ }^{-}$and $\mathrm{NO}_{2}{ }^{-}$ions reaches, respectively, in maximum 1.05 and $0.06 \mathrm{mg} \mathrm{L}^{-1}$ only in one point (middle depth of Upper Lake; Table 2). In other samples, their amounts range from 0.02 to $0.49 \mathrm{mg} \mathrm{L}^{-1}$ for $\mathrm{NO}_{3}{ }^{-}$and 0.001 to $0.012 \mathrm{mg} \mathrm{L}^{-1}$ for $\mathrm{NO}_{2}{ }^{-}$. Much greater value diversity is seen in the case of $\mathrm{NH}_{4}^{+}$concentration, which is very low in the surface layer of Upper Lake and Myrktjørna $\left(0.01 \mathrm{mg} \mathrm{L}^{-1}\right)$ and rises to $0.56 \mathrm{mg} \mathrm{L}^{-1}$ in waters outflowing from Myrktjørna Lake (point $3 \mathrm{H}$; Table 2; Fig. 3).

In hydrochemical terms, the waters from the lakes are mainly of the $\mathrm{HCO}_{3}-\mathrm{Cl}-\mathrm{Ca}-\mathrm{Mg}-\mathrm{Na}$ or $\mathrm{Cl}-\mathrm{HCO}_{3}-\mathrm{Ca}-$ $\mathrm{Mg}-\mathrm{Na}$ type. Calcium with $33-47 \%$ and bicarbonate $(39-49 \%)$ or chloride (39-52\%) ions predominates (Fig. 3). A very small share in the ionic composition of water has sulfate and potassium ions.

Apart from nitrogen compounds, the ion $\mathrm{PO}_{4}{ }^{3-}$ is a very important biogenic component. Its concentration in river and lake waters reaches a maximum value of $0.044 \mathrm{mg} \mathrm{L}^{-1}$ in the outflow from Myrktjørna (point $3 \mathrm{H}$; Table 1). Thus, over the relatively short distance from Upper Lake, where $\mathrm{PO}_{4}{ }^{3-}$ amounts only 0.005-0.009 $\mathrm{mg} \mathrm{L}^{-1}$, its concentration has increased a few times.

Relatively low dissolved organic carbon (DOC) values were found in the water of the lakes of the Brattegg Valley system. Among the three studied lakes, the maximum value of $0.78 \mathrm{mg} \mathrm{L}^{-1}$ was measured in the oldest Myrktjørna 
Table 2 Physical and chemical composition of Brattegg Valley lake and stream waters

\begin{tabular}{|c|c|c|c|c|c|c|c|c|c|c|c|c|c|c|c|}
\hline $\begin{array}{l}\text { No. of sample } \\
\text { (lake) }\end{array}$ & $\begin{array}{l}\text { Depth } \\
\text { (m) }\end{array}$ & $\begin{array}{l}\text { Temp } \\
\left({ }^{\circ} \mathrm{C}\right)\end{array}$ & $\begin{array}{l}\mathrm{EC} \\
\left(\mu \mathrm{S} \mathrm{cm}^{-1}\right)\end{array}$ & $\mathrm{pH}$ & $\mathrm{Ca}^{2+}$ & $\mathrm{Mg}^{2+}$ & $\mathrm{Na}^{+}$ & $\mathrm{K}^{+}$ & $\begin{array}{l}\mathrm{HCO}_{3}^{-} \\
\left(\mathrm{mg} \mathrm{L}^{-1}\right)\end{array}$ & $\mathrm{SO}_{4}{ }^{2-}$ & $\mathrm{Cl}^{-}$ & $\mathrm{NO}_{3}{ }^{-}$ & $\mathrm{NO}_{2}^{-}$ & $\mathrm{NH}_{4}^{+}$ & $\mathrm{PO}_{4}{ }^{3}-$ \\
\hline \multirow[t]{3}{*}{ 1A (upper) } & 0.50 & 1.5 & 30.2 & 6.61 & 4.45 & 1.49 & 2.65 & 0.35 & 13.4 & 2.14 & 7.72 & 0.10 & 0.003 & 0.01 & 0.007 \\
\hline & 20.0 & 1.1 & 37.9 & 6.33 & 3.42 & 2.25 & 2.66 & 0.29 & 15.9 & 2.28 & 8.10 & 1.05 & 0.059 & 0.15 & 0.009 \\
\hline & 35.0 & 1.0 & 38.6 & 6.26 & 3.02 & 2.06 & 3.36 & 0.43 & 16.5 & 3.21 & 7.18 & 0.49 & 0.003 & 0.20 & 0.005 \\
\hline 1B (upper) & 0.25 & 1.1 & 29.0 & nd & nd & nd & nd & nd & nd & nd & nd & nd & nd & nd & nd \\
\hline \multirow[t]{3}{*}{ 2C (middle) } & 0.50 & 4.9 & 35.4 & 6.47 & 3.00 & 1.73 & 2.77 & 0.27 & 13.4 & 1.07 & 8.23 & 0.04 & 0.002 & 0.47 & 0.023 \\
\hline & 3.00 & 4.6 & 30.2 & 6.54 & 3.61 & 1.51 & 2.93 & 0.23 & 12.2 & 1.88 & 7.59 & 0.41 & 0.012 & 0.16 & 0.013 \\
\hline & 6.00 & 4.5 & 30.5 & 6.75 & 3.26 & 1.45 & 2.86 & 0.24 & 12.8 & 1.61 & 6.66 & 0.20 & 0.003 & 0.07 & 0.021 \\
\hline 2D (stream) & 0.25 & 2.6 & 38.8 & 6.47 & 4.06 & 1.76 & 3.32 & 0.27 & 15.2 & 2.68 & 8.06 & 0.23 & 0.004 & 0.07 & 0.007 \\
\hline 2E (middle) & 0.25 & 2.5 & 32.0 & nd & nd & nd & nd & nd & nd & nd & nd & nd & nd & nd & nd \\
\hline $3 \mathrm{~F}$ (stream) & 0.25 & 4.0 & 35.2 & 6.68 & 4.64 & 1.51 & 2.66 & 0.26 & 15.3 & 2.62 & 7.18 & 0.14 & 0.001 & 0.37 & 0.009 \\
\hline \multirow[t]{3}{*}{ 3G (Myrktjørna) } & 0.50 & 7.6 & 50.5 & 6.77 & 3.69 & 2.01 & 2.99 & 0.29 & 12.2 & 3.19 & 8.53 & 0.06 & 0.002 & 0.01 & 0.018 \\
\hline & 2.60 & 7.3 & 36.4 & 6.52 & 3.59 & 1.90 & 3.17 & 0.44 & 14.6 & 2.68 & 7.84 & 0.02 & 0.003 & 0.15 & 0.008 \\
\hline & 5.00 & 7.1 & 35.2 & 6.55 & 2.40 & 2.39 & 3.09 & 0.30 & 14.6 & 2.41 & 7.93 & 0.04 & 0.001 & 0.20 & 0.009 \\
\hline 3H (Myrktjørna) & 0.25 & 7.8 & 39.8 & 6.41 & 3.33 & 1.90 & 3.94 & 0.36 & 18.3 & 2.14 & 8.10 & 0.40 & 0.001 & 0.56 & 0.044 \\
\hline
\end{tabular}

nd no data

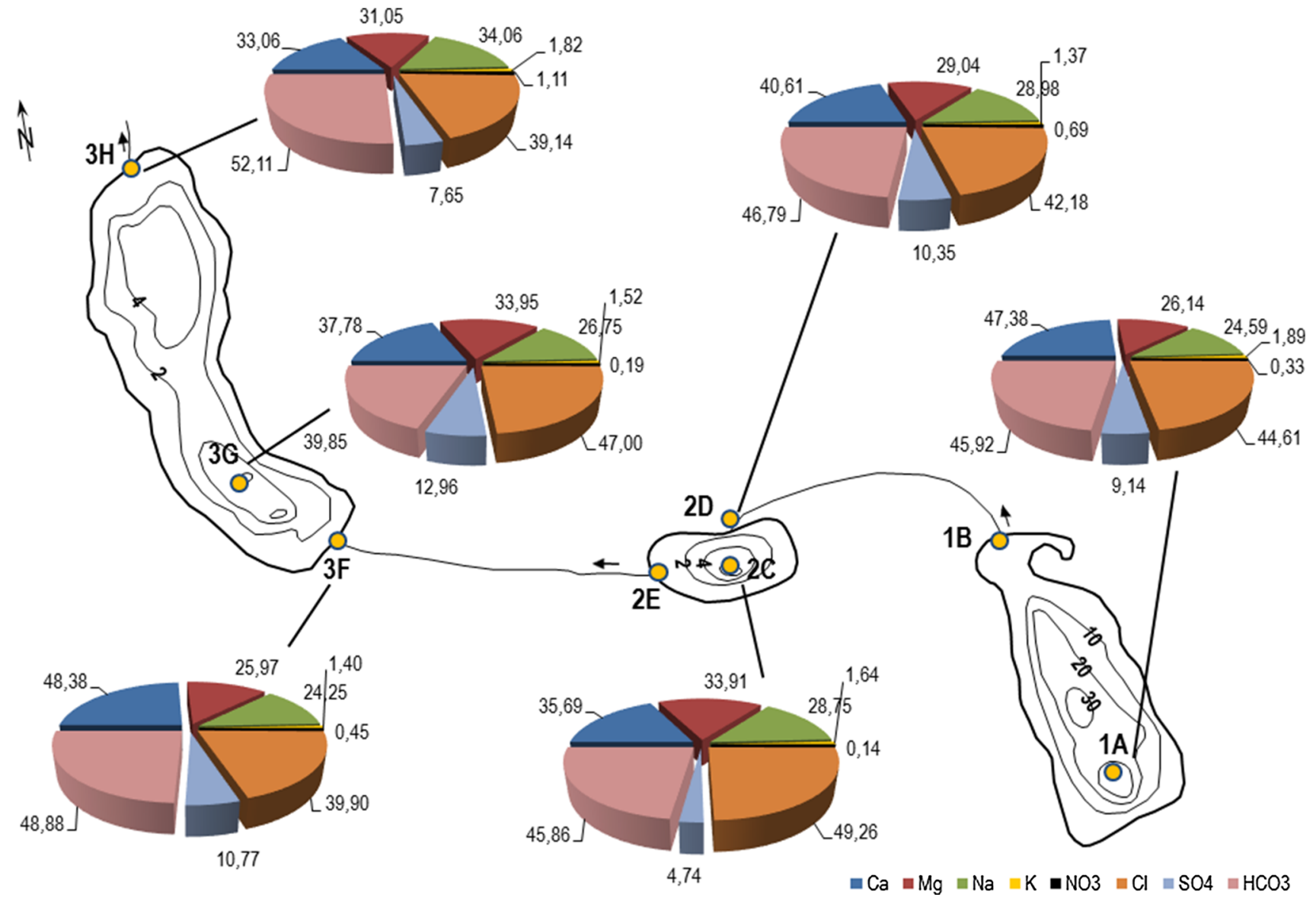

Fig. 3 Changes in water chemistry along the Brattegg river-lake system (pie charts showing the percentage of ions concentration) 
Table 3 Average concentration of basic biogenic components in lake waters

\begin{tabular}{|c|c|c|c|c|c|}
\hline No. of sample (lake) & N-tot $\left(\mathrm{mg} \mathrm{L}^{-1}\right)$ & $\mathrm{PO}_{4}{ }^{3-}\left(\mathrm{mg} \mathrm{L}^{-1}\right)$ & $\mathrm{NH}_{4}^{+}\left(\mathrm{mg} \mathrm{L}^{-1}\right)$ & $\mathrm{NO}_{3}{ }^{-}\left(\mathrm{mg} \mathrm{L}^{-1}\right)$ & $\mathrm{DOC}\left(\mathrm{mg} \mathrm{L}^{-1}\right)$ \\
\hline $1 \mathrm{~B}$ (upper) $^{\mathrm{a}}$ & 0.70 & 0.093 & 0.06 & 0.09 & 0.495 \\
\hline $2 \mathrm{E}(\text { middle })^{\mathrm{a}}$ & 0.90 & 0.021 & 0.01 & 0.00 & 0.711 \\
\hline 3H (Myrktjørna) ${ }^{\mathrm{a}}$ & 0.30 & 0.044 & 0.05 & 0.11 & 0.562 \\
\hline $1 \mathrm{~B}$ (upper) $^{\mathrm{b}}$ & 0.50 & 0.039 & 0.03 & 0.02 & 0.440 \\
\hline 2E $(\text { middle })^{\mathrm{b}}$ & 0.50 & 0.020 & 0.02 & 0.04 & 0.295 \\
\hline $3 \mathrm{H}\left(\right.$ Myrktjørna) ${ }^{\mathrm{b}}$ & 0.05 & 0.047 & 0.03 & 0.02 & 0.780 \\
\hline
\end{tabular}

$\mathrm{N}$-tot nitrogen total, $\mathrm{PO}_{4}^{3-}$ phosphorus phosphate, $\mathrm{NH}_{4}^{+}$ammonia nitrogen, $\mathrm{NO}_{3}^{-}$nitrate nitrogen, $\mathrm{DOC}$ dissolved organic carbon

a August 2010

b August 2011

Table 4 Concentration of microelements in Brattegg Valley lake and stream waters

\begin{tabular}{|c|c|c|c|c|c|c|c|c|c|c|c|}
\hline $\begin{array}{l}\text { No. of sample } \\
\text { (lake) }\end{array}$ & $\begin{array}{l}\text { Depth } \\
(\mathrm{m})\end{array}$ & $\begin{array}{l}\mathrm{Fe} \\
\left(\mathrm{mg} \mathrm{L}^{-1}\right)\end{array}$ & $\begin{array}{l}\mathrm{Mn} \\
\left(\mathrm{mg} \mathrm{L}^{-1}\right)\end{array}$ & $\begin{array}{l}\mathrm{Pb} \\
\left(\mu \mathrm{g} \mathrm{L}^{-1}\right)\end{array}$ & $\begin{array}{l}\mathrm{Cd} \\
\left(\mu \mathrm{g} \mathrm{L}^{-1}\right)\end{array}$ & $\begin{array}{l}\mathrm{Cu} \\
\left(\mu \mathrm{g} \mathrm{L}^{-1}\right)\end{array}$ & $\begin{array}{l}\mathrm{Zn} \\
\left(\mu \mathrm{g} \mathrm{L}^{-1}\right)\end{array}$ & $\begin{array}{l}\mathrm{Al} \\
\left(\mu \mathrm{g} \mathrm{L}^{-1}\right)\end{array}$ & $\begin{array}{l}\mathrm{Ni} \\
\left(\mu \mathrm{g} \mathrm{L}^{-1}\right)\end{array}$ & $\begin{array}{l}\mathrm{Cr} \\
\left(\mu \mathrm{g} \mathrm{L}^{-1}\right)\end{array}$ & $\begin{array}{l}\text { Co } \\
\left(\mu \mathrm{g} \mathrm{L}^{-1}\right)\end{array}$ \\
\hline \multirow[t]{3}{*}{ 1A (upper) } & 0.50 & 0.05 & 0.01 & 0.50 & 0.36 & 0.19 & 19.7 & 79.6 & 4.84 & 0.00 & 1.74 \\
\hline & 20.0 & 0.54 & 0.05 & 0.40 & 0.07 & 0.31 & 9.04 & 406 & 0.68 & 0.73 & 3.78 \\
\hline & 35.0 & 0.49 & 0.06 & 0.49 & 0.30 & 0.77 & 13.1 & 499 & 4.22 & 0.63 & 4.42 \\
\hline \multirow[t]{3}{*}{ 2C (middle) } & 0.50 & 0.10 & 0.03 & 6.09 & 0.10 & 0.21 & 2.52 & 39.8 & 3.36 & 0.14 & 3.46 \\
\hline & 3.00 & 0.00 & 0.03 & 2.01 & 0.02 & 0.23 & 6.02 & 111 & 0.00 & 0.19 & 0.69 \\
\hline & 6.00 & 0.00 & 0.00 & 2.58 & 0.02 & 0.19 & 7.47 & 2.38 & 1.44 & 0.00 & 1.35 \\
\hline 2D (inflow) & 0.25 & 0.15 & 0.05 & 0.26 & 0.36 & 0.20 & 6.76 & 106 & 1.48 & 1.79 & 0.00 \\
\hline 3F (Myrktjørna) & 0.25 & 0.00 & 0.02 & 0.00 & 0.00 & 0.09 & 0.59 & 41.4 & 0.00 & 0.00 & 2.30 \\
\hline \multirow[t]{3}{*}{ 3G (Myrktjørna) } & 0.50 & 0.00 & 0.03 & 0.34 & 0.12 & 0.29 & 5.13 & 113 & 0.50 & 0.00 & 0.71 \\
\hline & 2.60 & 0.00 & 0.01 & 5.97 & 0.15 & 0.28 & 6.68 & 3.42 & 0.76 & 0.00 & 2.02 \\
\hline & 5.00 & 0.14 & 0.04 & 2.40 & 0.09 & 0.22 & 12.4 & 185 & 0.20 & 0.15 & 4.95 \\
\hline 3H (Myrktjørna) & 0.25 & 0.50 & 0.03 & 0.18 & 0.16 & 0.26 & 3.05 & 214 & 0.62 & 0.64 & 4.66 \\
\hline
\end{tabular}

Lake, but the lowest concentration of DOC was in the waters of the two younger lakes of the Brattegg Valley system (sample Nos. 1B, 2E, Fig. 3; Table 3).

Physical and some of the chemical features of water change with the depth of all studied lakes (Tables 1,2). The vertical zonality is manifested in a drop of temperature, an increase (in Upper Lake) or decrease (in Middle and Myrktjørna Lakes) of EC and contents of some macroand microelements. In the deepest lake, the concentration of most macrocomponents such as $\mathrm{Mg}^{2+}, \mathrm{Na}^{+}, \mathrm{K}^{+}$, $\mathrm{HCO}_{3}{ }^{-}, \mathrm{SO}_{4}{ }^{2-}, \mathrm{NH}_{4}{ }^{+}$increases with depth.

A very slight decrease is seen in the case of $\mathrm{Ca}^{2+}$ ion and $\mathrm{pH}$ (from 6.61 to 6.26), while maximum values of $\mathrm{Cl}^{-}$, $\mathrm{NO}_{3}{ }^{-}$and $\mathrm{NO}_{2}{ }^{-}$ions are observed in the middle layer (Table 2). In shallow lakes (Middle and Myrktjørna), trends in the concentrations of various ions proceed differently. In both cases, the greater concentrations of chloride are to be found in the upper layers of subsurface waters. This may be associated with more than in Upper Lake recharge of lake waters with this anion by aerosols entrained from the coast of the Greenland Sea.

From the group of 10 analyzed metals, increased concentrations of iron and aluminum, compared to the other microelements, are present in lake and stream waters, respectively, up to $0.54 \mathrm{mg} \mathrm{Fe} \mathrm{L}^{-1}$ and $0.50 \mu \mathrm{g} \mathrm{Al} \mathrm{L}-1$ (Table 4; Fig. 4). The content of metals is different in every lake and stream water and varies with depth. The maximum concentrations of most trace elements, except lead and cobalt, occur in the waters of Upper Lake No. 1. Higher amounts of such metals as $\mathrm{Cd}, \mathrm{Pb}, \mathrm{Zn}$ and $\mathrm{Ni}$ are present in the surface layer, $\mathrm{Fe}$ and $\mathrm{Cr}$ in the middle layer and $\mathrm{Mn}, \mathrm{Cu}$ and $\mathrm{Al}$ in the lower water layer of this lake (Table 4).

The water of the Middle Lake is characterized by very low or almost the lack of Fe and Mn but with the maximum of lead concentrations, up to $6.09 \mathrm{mg} \mathrm{L}^{-1}$, among the all 


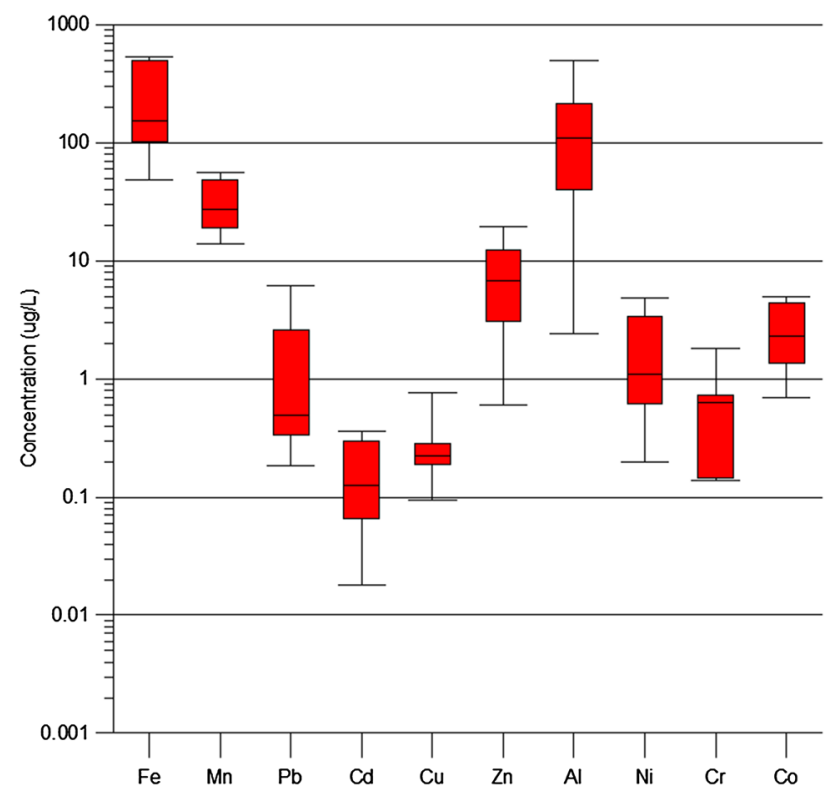

Fig. 4 Concentrations of microelements in all water samples

samples population (Table 4). Interesting results were obtained for aluminum, namely that the highest content reaching over $111 \mu \mathrm{g} \mathrm{L}^{-1}$ occurs in the middle part on the depth of $3 \mathrm{~m}$. Close to the bottom $\mathrm{Al}$ content decreases to $2.38 \mu \mathrm{g} \mathrm{L}^{-1}$, which is the minimum value among all samples. Low concentrations of Fe were found in the water of the largest Myrktjørna lake. Its deepest water contains the highest cobalt concentration up to nearly $5.00 \mu \mathrm{g} \mathrm{L}^{-1}$. Along with its depth, the concentration of $\mathrm{Fe}, \mathrm{Mn}, \mathrm{Zn}, \mathrm{Al}$, $\mathrm{Cr}$ and $\mathrm{Co}$ increases.

The stratification of lake waters in the Brattegg catchment is also visible in their isotopic composition. In lake waters, the $\delta^{18} \mathrm{O}$ ranged -10.58 to $-10.92 \%$ and $\delta^{2} \mathrm{H}$ -70.8 to $-72.3 \%$ (Fig. 5 ). The majority of oxygen and hydrogen isotope values are lying close to the World Meteoric Water Line (WMWL) described by Craig (1961) and to the local line made for the Spitsbergen (Glasser and Hambrey 2002). All points, except one sample taken from the middle layer (depth of $20 \mathrm{~m}$ ) of Upper Lake, are lying on one line.

\section{Discussion}

In the young postglacial lake-river system of the Brattegg Valley, formed after the recession of permanent ice cover of the last glaciation, a unique aquatic ecosystem gradually colonized by various organisms was created. Environmental conditions of life are mostly determined by the physical and chemical properties of water, which changes from the beginning of the Brattegg River, through a system

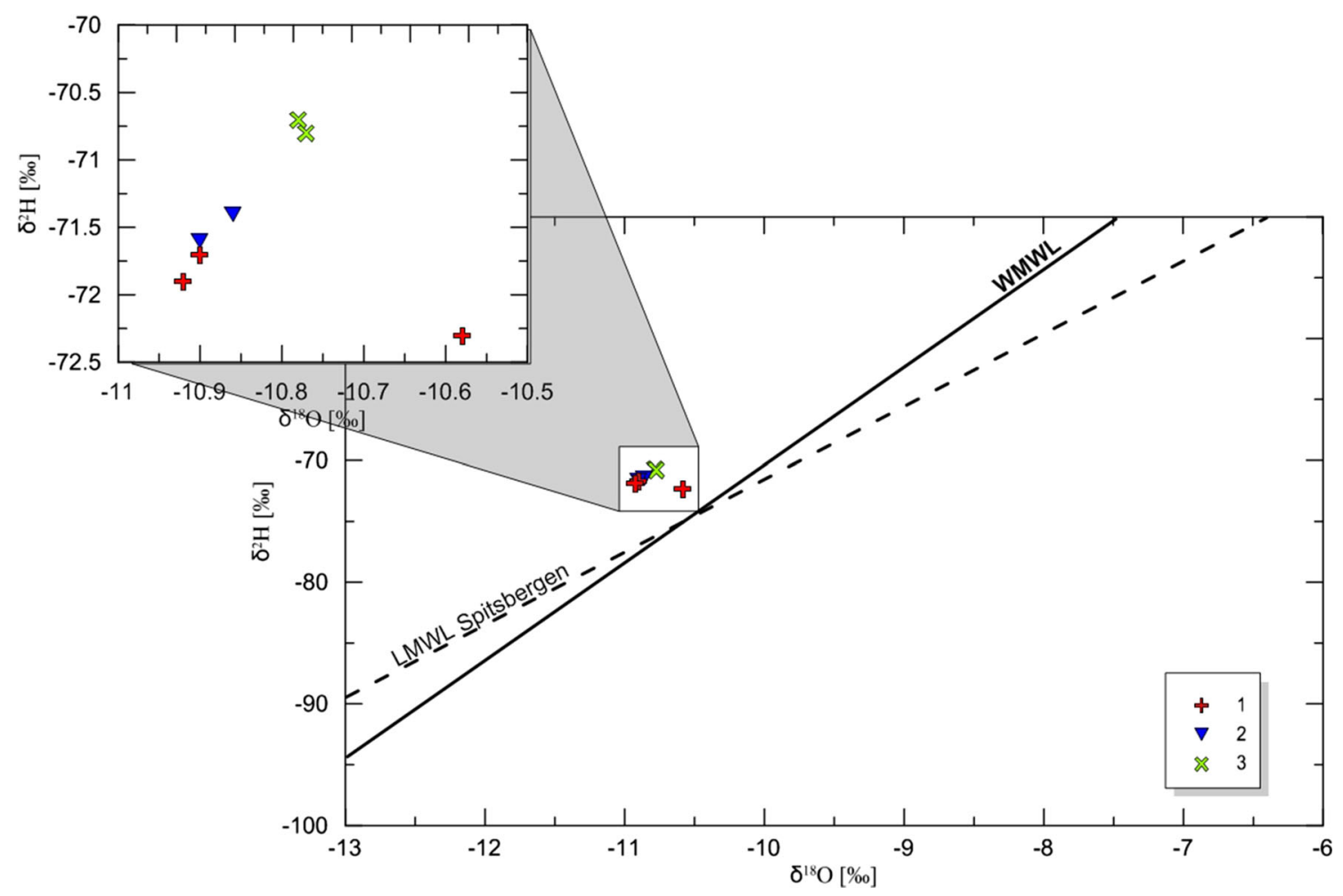

Fig. 5 Isotopic composition of lake water in the Brattegg River catchment (1-3 lake numbers; WMWL World Meteoric Water Line, $L M W L$ Local Meteoric Water Line) 
of three lakes, until the mouth of the Greenland Sea. Intensive river drainage causes erosion of bedrock and transport of suspended material downstream making as a result a gradual filling and shallowing of lower lake depressions (Middle and Myrktjørna). As a result, the analyzed river-lake system has a specific thermal and hydrogeochemical regime of water, which affects biodiversity.

The three analyzed lakes are permanent, in contrast to the ephemeral, small and shallow reservoirs appearing in different parts of the study area, especially in the marginal zone of adjacent and large Werenskiold glacier. The flow character of the lake system, recharged in the upper part by melting glacier water and below both by meltwater from snow patches, as well as water of the permafrost active layer, is reflected in differences of their temperature and chemistry of waters. The location of the tested catchment in the polar region causes that water flow of the Brattegg Valley system runs during the summer. River runoff starts at the turn of May and June and stops completely even by the end of September (Marszałek and Wasik 2013). Thus, the thermal regime of lake-river system depends mainly on air temperature. Higher air temperatures during summer are responsible for stronger glacier ablation that recharges Upper Lake with cold water having low mineralization. As a result, the temperature of Upper Lake is in maximum $1.5{ }^{\circ} \mathrm{C}$. Down of the stream course, the temperature of subsurface water, including Middle and Myrktjørna Lakes, is getting warmer, reaching $7.6{ }^{\circ} \mathrm{C}$ at the outflow from Myrktjørna Lake (Table 1). Measurements of the Brattegg River thermal regime, made during the summer season of 2005 (Marszałek and Wassik 2013), show the varying of water temperature from nearly 0.0 to $9.6^{\circ} \mathrm{C}$. According to these measurements, water temperature at the turn of May and June is close to $0{ }^{\circ} \mathrm{C}$ and then it gradually increases to $6{ }^{\circ} \mathrm{C}$ and sometimes over $8{ }^{\circ} \mathrm{C}$ by the end of August. At the beginning of September, the water temperature decreases gradually to $3.0-4.0^{\circ} \mathrm{C}$, and in the middle of September it rapidly drops to nearly $0{ }^{\circ} \mathrm{C}$, till the flow in the rivers stops completely. The daily amplitude of water temperature in Brattegg River was $1.5-2.0{ }^{\circ} \mathrm{C}$ (Marszałek and Wąsik 2013).

Recharge of analyzed river-lake system by low-mineralized water from melting glacier, snow and the active layer reduces water mineralization. The hydrodynamic and hydrogeochemical regime of water is also determined by precipitation, which in this part of Spitsbergen can reach the values of even $120 \mathrm{~mm}$ per month in summer (Pereyma et al. 2013). Intense rainfall causes a significant increase in water level and flow of the river, and the slight rise of water level in the lakes. However, the morphological location of the lakes in local flat areas affects the growth of the lake surface, but their water levels raise relatively little.
The chemical composition of lake water is formed by both abiotic and biotic factors. The first ones are related to physicochemical processes in the weathered upper part of the rock profile where waters are supplied by dissolved material. It occurs mainly in the active layer of permafrost having a relatively small thickness in this area, rarely exceeding $2 \mathrm{~m}$ (Migała 1994). Short residence time of groundwater in the active layer due to its fast flow in wellpermeable rock environment (Marszałek et al. 2013b) determines their low mineralization. The TDS (total dissolved solids) of groundwater in a form of subsurface runoff and surface water is similar. The electrolytic conductivity of surface water in the Brattegg catchment is relatively low, mainly $30.0-50.0 \mu \mathrm{S} \mathrm{cm}^{-1}$ (Table 2). These values correspond to the lower limit of the EC background (36.0-188 $\mu \mathrm{S} \mathrm{cm}^{-1}$ ) specified for this part of Spitsbergen during the summer period of 2005 (Marszałek and Wąsik 2013). Additional dilution of water is caused by poorly mineralized water coming from the glacier and snow cover. The growth of EC with depth of Upper Lake is probably caused by the stagnation of water in the deeper part, while the decline in the other elderly and shallow lakes could be associated with their flow character.

The predomination of bicarbonates in the chemical composition of lakes and river water seems to be typical considering their recharge by groundwater related to the active layer of permafrost. Studies carried out in different regions show that this anion predominates in low-mineralized groundwater of shallow circulation and surface water of temperate climatic zone (Macioszczyk and Dobrzyński 2002). The concentration of bicarbonates in surface waters, up to $18.3 \mathrm{mg} \mathrm{L}^{-1}$, is much lower than the average content of $\mathrm{HCO}_{3}^{-}$in shallow groundwater of permafrost areas $\left(82.2 \mathrm{mg} \mathrm{L}^{-1}\right.$ according to Macioszczyk and Dobrzyński 2002). The lack of carbonate rocks in the studied catchment indicates that the source of bicarbonates is weathering of the primary silicates and aluminosilicates in metamorphic rocks. Major cations as calcium, magnesium, potassium and sodium originate from the weathering of crystalline rock minerals as well, but the presence of $\mathrm{Na}^{+}$ion may also be associated with aerosols of the Greenland Sea waters. Typical features of subsurface water in Middle and Myrktjørna Lakes are domination of chlorides among the anions instead of the $\mathrm{HCO}_{3}{ }^{-}$in Upper Lake. The concentration of chlorides, in the range of 6.66-8.53 mg L $\mathrm{m}^{-1}$, is similar to average content for river water amounting to $8.00 \mathrm{mg} \mathrm{L}^{-1}$ (Macioszczyk and Dobrzyński 2002). The presence of this element can be related to the seawater transported in the form of aerosol to the Brattegg Valley from the sea shore. Another feature of all lake waters is a very small amount of sulfates.

Taking into account the concentration of main ions, the lake waters represent a few chemical types depending on the 
Fig. 6 Chemical composition of water shown on Piper diagram (1-3 lake numbers)

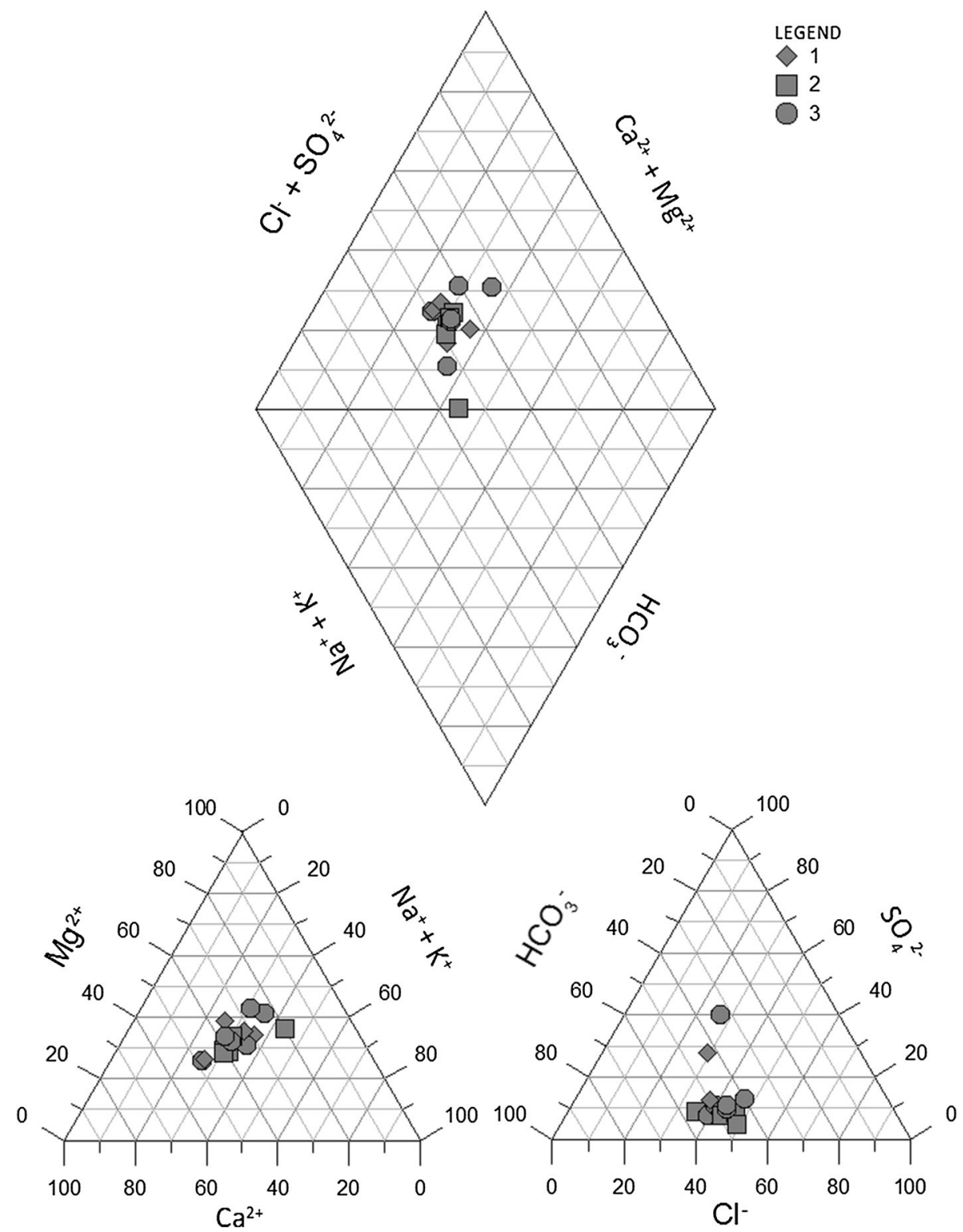

depth of sampling (Fig. 6). Subsurface water on the depth of $0.5 \mathrm{~m}$ has $\mathrm{HCO}_{3}-\mathrm{Cl}-\mathrm{Ca}-\mathrm{Mg}-\mathrm{Na}$ type for Upper Lake and $\mathrm{Cl}-\mathrm{HCO}_{3}-\mathrm{Ca}-\mathrm{Mg}-\mathrm{Na}$ for two others, whereas deeper layers (middle and bottom) of waters in Upper Lake have $\mathrm{HCO}_{3}-$ $\mathrm{Cl}-\mathrm{Mg}-\mathrm{Ca}-\mathrm{Na}$ and $\mathrm{HCO}_{3}-\mathrm{Cl}-\mathrm{Ca}-\mathrm{Na}-\mathrm{Mg}$ for Middle Lake. The type of water in the Myrktjørna Lake differs in case of cations: $\mathrm{HCO}_{3}-\mathrm{Cl}-\mathrm{Ca}-\mathrm{Mg}-\mathrm{Na}$ for middle part of water column and $\mathrm{HCO}_{3}-\mathrm{Cl}-\mathrm{Mg}-\mathrm{Na}-\mathrm{Ca}$ close to the bottom.

The water of the suprapermafrost zone in this part of Spitsbergen has also similar character: $\mathrm{HCO}_{3}-\mathrm{Mg}-\mathrm{Ca}$ and $\mathrm{HCO}_{3}-\mathrm{Ca}-\mathrm{Mg}$ (Marszałek and Wạsik 2013).

The existence of bird colonies in the Wedel Jarlsberg Land is an important biotic factor contributing to the increase in waters mineralization, $\mathrm{pH}$ and some biogenic components. The studied small catchment belongs to the areas of the Spitsbergen rather rarely visited by birds.
Birds' habitats are mainly observed close to the Myrktjørna and in the upper part of the adjacent Gullichsenfjellet massif. So, the contribution of biotic factor to forming of chemical composition of water is limited compared with the influence of abiotic factors.

From the main biogenic components, only the amount of DOC increased along the flow way from Upper Lake $\left(0.440 \mathrm{mg} \mathrm{L}^{-1}\right)$ to Myrktjørna, with the maximum value up to $0.780 \mathrm{mg} \mathrm{L}^{-1}$ (Table 3). Such a tendency was also observed in the case of $\mathrm{PO}_{4}{ }^{3-}$ ion (from 0.039 to $0.047 \mathrm{mg} \mathrm{L}^{-1}$ ), but only in the samples from August of 2011. The characteristic higher content of DOC in the Upper Lake $\left(0.440-0.495 \mathrm{mg} \mathrm{L}^{-1}\right)$ may be a consequence of organic carbon supply of glacial origin. Such phenomenon has already been observed in subglacial environments (Stibal et al. 2008; Zdanowski et al. 2013). 
There is no observed significant change in the concentration of ammonia along the flow way from Upper Lake to the Myrktjørna in contrast to the changes with depth. The concentration of this component is a little lower in water of the Middle Lake $\left(0.01-0.02 \mathrm{mg} \mathrm{L}^{-1}\right)$ in comparison with the other two lakes $\left(0.03-0.06 \mathrm{mg} \mathrm{L}^{-1}\right)$. The increase in the amount of ammonia with the depth may be associated with a significant amount of iron in the deeper layers of water (Bonilla 2005). In the Middle Lake, surface water may be associated with the content from soil humus. This is confirmed by results of DOC measurements.

The highest values of ammonia and DOC found in the lowest lake (Myrktjørna) have most likely a direct relationship with the age of the lake and well-developed microbial mats, the presence of planktonic microorganisms, fish and also birds (mainly little auks and geese) (Isaksen and Bakken 1995). In higher lakes (Upper and Middle), there was not observed such a diverse biocenosis (Górniak et al. 2016). The source of the ammonia in the Myrktjørna Lake can also be the abundance of fish and zooplankton. In polar lakes, these organisms can be both sources and sinks of nitrogen $(\mathrm{N})$ and phosphorus (P) through the consumption of organic $\mathrm{N}$ and $\mathrm{P}$, and subsequent excretion of bioavailable inorganic forms (Johnson 2009; Johnson and Luecke 2012). Higher than in other lakes and stream water content of nutrients in the Myrktjørna Lake is the result of runoff from the catchment with well-developed tundra as well as bottom sediments and microbial mats.

Apart from the above-described factors, thermokarst processes (permafrost thawing and erosion) play an important role in many lake systems throughout the Arctic and over a wide range of soil and climate regimes (e.g., Jorgenson and Osterkamp 2005; Jones et al. 2011; Vincent et al. 2013). Leached and dissoluted material from the soils and weathered rock enrich surface and groundwater in chemical compounds. Poorly developed arctic soils (type of Cryosols, Leptosols and Gleysols) can deliver a load of chemical elements to water. Cryosols contain 3-10\% of carbonates, whereas soils located close to breeding colonies of birds have an elevated organic matter content and high concentration of nitrogen and phosphorus of animal origin (Kabała and Korabiewski 2013). Analysis of soil water extracts made in 2005 by Marszałek and Waqsik (unpublished) in the Brattegg catchment show considerable content of iron (up to $1.28 \mathrm{mg} \mathrm{L}^{-1}$ ) and, respectively, up to: copper $\left(37.5 \mu \mathrm{g} \mathrm{L}^{-1}\right)$, zinc $\left(40.1 \mu \mathrm{g} \mathrm{L}^{-1}\right)$, nitrate (1.14 $\left.\mathrm{m} \mathrm{L}^{-1}\right)$, nitrite $\left(0.32 \mathrm{mg} \mathrm{L}^{-1}\right)$ and phosphate (7.73 $\mathrm{mg} \mathrm{L}^{-1}$ ).

The natural concentrations of trace metals in surface waters are rather low and depends both on geological and on anthropogenic factors. According to Kabata-Pendias and Pendias (1999), the average content of some trace metals is as follows: for $\mathrm{Al}-64.0 \mu \mathrm{g} \mathrm{L}^{-1}, \mathrm{Zn}-$ $10.0 \mu \mathrm{g} \mathrm{L}^{-1}, \mathrm{~Pb}-0.20 \mu \mathrm{g} \mathrm{L}^{-1}, \mathrm{Cu}-1.00-2.00 \mu \mathrm{g} \mathrm{L}^{-1}$, $\mathrm{Ni}-1.00 \mu \mathrm{g} \mathrm{L}^{-1}, \mathrm{Cr}-0.50 \mu \mathrm{g} \mathrm{L}^{-1}, \mathrm{Co}-0.20 \mu \mathrm{g} \mathrm{L}^{-1}$, $\mathrm{Cd}-0.02 \mu \mathrm{g} \mathrm{L}^{-1}$. The average iron concentration range is very wide, from $10.0 \mu \mathrm{g} \mathrm{L}^{-1}$ to even $1400 \mu \mathrm{g} \mathrm{L}^{-1}$ (Kabata-Pendias and Pendias 1999). The results of analyzed samples show that the maximum concentrations of some metals in lake waters far exceed the average values. This particularly applies to such trace elements as aluminum, lead, cobalt, nickel and cadmium. The slightly acidic $\mathrm{pH}$ is not conducive to migration of metals from the rocks to water environment; hence, a significant part in the supply of metals may be played by biotic factors. Some episodic polluted precipitation can deliver from Europe an input of nitrogen concentration $\left(1.15 \mathrm{mg} \mathrm{L}^{-1} \mathrm{NO}_{3}-\mathrm{N}\right.$ and $1.20 \mathrm{mg}$ $\mathrm{L}^{-1} \mathrm{NH}_{4}-\mathrm{N}$ ) to Svalbard (Hodson et al. 2010).

Apart from chemical variability also, the isotopic composition of lake waters changes both along the river-lake system and in vertical profile. The values of stable isotopes depend mainly on the phase transformation of the atmospheric portion of the water in the water cycle (Zuber 2007). In lake waters, the value range is small: from -10.9 to $-10.6 \%$ for $\delta^{18} \mathrm{O}$ and from -72.3 to $-70.8 \%$ for $\delta^{2} \mathrm{H}$. The analyzed Upper Lakes water is characterized by more negative values of oxygen and hydrogen (Fig. 5). A small change of values may be due to the relatively short time of downstream water flow, from upper to lower parts of the catchment. However, the differences may also be within the limits of analysis error. Isotopic fractionation of water, related to evaporation process (Hoefs 2009), causes the enrichment of the heavy isotopic species along the way of flow water starting from Upper cirques lake to the Myrktjørna. Differences in the isotopic composition of the water sample taken from the middle part of the Upper Lake can probably result from inflow of younger water to circus deep depression.

The isotopic composition of polar lake water in Spitsbergen is similar to the fresh and young groundwater from the territory of central Europe, with values in the range of -9.30 to $-10.5 \%$ for $\delta^{18} \mathrm{O}$ and from about -63.0 to $-75.0 \%$ for $\delta^{2} \mathrm{H}$ (Zuber 2007).

\section{Conclusions}

The Brattegg river-lake system of west Spitsbergen was formed after the last deglaciation. It is a good example of anthropogenically undisturbed polar environment allowing the study of hydrochemical living conditions and the development of various organisms in the waters of three lakes connected by a river. The diversified morphometry of the lakes and their position in the Brattegg River catchment determine the differences in their chemical composition 
and physical properties of water, and this creates habitat for certain species of organisms. The lakes are characterized by low mineralization and temperature of water, the dominance of $\mathrm{HCO}_{3}$ or $\mathrm{Cl}, \mathrm{Ca}, \mathrm{Mg}$ and $\mathrm{Na}$ ions and increased concentrations of iron and aluminum. The highest values of ammonia and DOC found in the lowest Myrktjørna Lake seem to be related to the presence of such aquatic organisms as phytoplankton, zooplankton and fish, as well as birds.

Acknowledgements This work was founded by Polish Ministry of Science and Higher Education as Grant N-N304-242237.

Open Access This article is distributed under the terms of the Creative Commons Attribution 4.0 International License (http://creative commons.org/licenses/by/4.0/), which permits unrestricted use, distribution, and reproduction in any medium, provided you give appropriate credit to the original author(s) and the source, provide a link to the Creative Commons license, and indicate if changes were made.

\section{References}

Bernstein L, Bosch P, Canziani O, Chen Z, Christ R, Davidson O et al (2007) Climate change 2007: Synthesis report. https://www.ipcc. ch/pdf/assessment-report/ar4/syr/ar4_syr.pdf

Bieroński J (1977) Chemical properties of water in the Hornsund area. In: Proc Symp Spitsbergen Wrocław, pp 39-43 (in Polish)

Birkenmajer K (2013) Outline of geological structure (pre-Quaternary rocks). Geographical environment in the vicinity of the Stanisław Baranowski Polar Station-Werenskioldbreen. In: Zwoliński Z, Kostrzewski A, Pulina M (eds) Ancient and modern geoecosystems of Spitsbergen. Bogucki Wydawnictwo Naukowe, Poznań, pp 103-104

Bonilla S (2005) Benthic and planktonic algal communities in a High Arctic lake: pigment structure and contrasting responses to nutrient enrichment. J Phycol 41:120-1130

Bukowska-Jania E (2003) The role of glacier systems in the migration of calcium carbonate in the natural environment, based on Svalbard and north-western parts of Poland. Prace Naukowe UŚ $\mathrm{Nr} 2103$, Wydawnictwo Uniwersytetu Śląskiego, Katowice (in Polish)

Cooper RJ, Wadham JL, Tranter M, Peters N (2002) Groundwater hydrochemistry in the active layer of the proglacial zone, Finsterwalderbreen, Svalbard. J Hydrol 269:208-223

Craig H (1961) Isotopic variations in meteoric waters. Science New Ser 133:1702-1703

Cressie NAC (1991) Statistics for spatial data. Wiley, New York

Glasser NF, Hambrey MJ (2002) $\delta \mathrm{D}-\delta^{18} \mathrm{O}$ relationships on a polythermal valley glacier: Midtre Lovénbreen, Svalbard. Pol Res 21:123-131

Górniak D, Marszałek H, Jankowska K, Dunalska J (2016) Bacterial community succession in an Arctic lake-stream system (Brattegg Valley, SW Spitsbergen). Boreal Environ Res 21:115-133

Haldorsen S, Lauritzen SE (1995) Subpermafrost groundwater in Spitsbergen. In: Banks S, Banks D (eds) Hydrogeology of hard rocks. Mem. of the 24th Congress of the IAH, NGU, Trondheim, Norway, pp 940-949

Haldorsen S, Heim M, Lauritzen SE (1996) Subpermafrost groundwater. Western Svalbard. Nord Hydrol 27:57-68

Hanssen-Bauer I (2002a) Climate trends in the European Arctic the last 100 years. In: Ørbæk JB, Holman, Neuber R, Plag HP, Lefauconnier B, De Prisco G, Ho H (eds) Proceedings from the sixth Ny-Ålesund International Scientific Seminar. Polar Environmental Center, Troms $\varnothing$, Norway, 8-10 October 2002, Norsk Polarinstitutt, Internrapport Nr, vol 10, pp 29-32

Hanssen-Bauer I (2002b) Temperature and precipitation in Svalbard 1912-2050: measurements and scenarios. Polar Rec 38:225-232

Hodson A, Roberts TJ, Engval AC, Holmen K, Mumford P (2010) Glacier ecosystem response to episodic nitrogen enrichment in Svalbard, European High Arctic. Biogeochemistry 98:171-184

Hoefs J (2009) Stable isotope geochemistry. Springer, Berlin

Isaksen K, Bakken V (eds) (1995) Seabird populations in the Northern Barents Sea. Source data for the impact assessment of the effects of oil drilling activity. Norsk Polarinstitutt, Oslo

Jania J, Hagen JO (eds) (1996) Mass balance of Arctic glaciers. IASC Report No. 5. Sosnowiec-Oslo. University of Silesia, Poland

Johnson CR (2009) Consumer-driven nutrient recycling in Arctic Alaskan lakes: controls, importance for primary productivity, and influence on nutrient limitation. Graduate Theses and Dissertations. Paper 417. http://digitalcommons.usu.edu/etd/417

Johnson CR, Luecke C (2012) Copepod dominance contributes to phytoplankton nitrogen deficiency in lakes during periods of low precipitation. J Plankton Res. doi:10.1093/plankt/fbs009, available online at www.plankt.oxfordjournals.org

Jones BM, Grosse G, Arp CD, Jones MC, Walter AM, Romanovsky VE (2011) Modern thermokarst lake dynamics in the continuous permafrost zone, northern Seward Peninsula. Alaska. J Geophys Res 116:G00M03. doi:10.1029/2011JG001666

Jorgenson MT, Osterkamp TE (2005) Response of boreal ecosystems to varying modes of permafrost degradation. Can J For Res 35:2100-2111

Kabała C, Korabiewski B (2013) Soils. Geographical environment in the vicinity of the Stanisław Baranowski Polar StationWerenskioldbreen. In: Zwoliński Z, Kostrzewski A, Pulina M (eds) Ancient and modern geoecosystems of Spitsbergen. Bogucki Wydawnictwo Naukowe, Poznań, pp 114-118

Kabata-Pendias A, Pendias H (1999) Biogeochemistry of trace elements. Wydawnictwo Naukowe PWN, Warszawa (in Polish)

Kolondra L (1995) Werenskioldbreen and surrounding areas Spitsbergen map, Svalbard, Norway (1:25 000), Copyright: Faculty of Earth Sciences, University of Silesia, Sosnowiec and Norwegian Polar Institute, Troms $\varnothing$

Krawczyk WE (1992) Chemical characteristic of water circulating in the Werenskioldglacier (SW Spitsbergen). In: Proceedings of the 2nd international symposium of glacier caves and Karst in polar regions. Sosnowiec, pp 65-80

Krawczyk WE, Bartoszewski S, Siwek K (2008) Rain water chemistry at Calypsobyen, Svalbard. Pol Polar Res 29:149-162

Krzyszowska A (1985) Chemistry of freshwater of the Fugleberget drainage basin. Pol Polar Res 6:341-347

Macioszczyk A, Dobrzyński D (2002) Hydrogeochemistry of groundwater active exchange zone. Wydawnictwo Naukowe PWN, Warszawa (in Polish)

Manecki A, Czerny J, Kieres A, Manecki M, Rajchel J (1993) Geological map of the SW part of Wedel Jarlsberg Land Spitsbergen (1:25 000). Wydawnictwo AGH, Kraków

Marszałek H, Wąsik M (2013) Some physico-chemical features of water in suprapermafrost zone in the Hornsund region ( $\mathrm{SW}$ Spitsbergen). Biul PIG 456:397-404

Marszałek H, Rysiukiewicz M, Staśko S, Wąsik M (2013a) Waters. Geographical environment in the vicinity of the Stanisław Baranowski Polar Station-Werenskioldbreen. In: Zwoliński Z, Kostrzewski A, Pulina M (eds) Ancient and modern geoecosystems of Spitsbergen. Bogucki Wydawnictwo Naukowe, Poznań, pp 125-131

Marszałek H, Staśko S, Wąsik M (2013b) Estimation of subsurface runoff in the Hornsund region (SW Spitsbergen). Biul PIG 456:391-395 (in Polish) 
Migała K (1994) Features of active layer in climatic conditions of Spitsbergen. Acta Univ Wratisl 1590. Prace Inst Geograf seria C. Meteorologia i Klimatologia 1:79-111 (in Polish)

Olichwer T, Tarka R, Modelska M (2013) Chemical composition of groundwaters in the Hornsund region, S Spitsbergen. Hydrol Res 44:117-130

Pereyma J, Migała K, Sikora S (2013) Climate. Geographical environment in the vicinity of the Stanisław Baranowski Polar Station-Werenskioldbreen. In: Zwoliński Z, Kostrzewski A, Pulina M (eds) Ancient and modern geoecosystems of Spitsbergen. Bogucki Wydawnictwo Naukowe, Poznań, pp 118-121

Pulina M, Krawczyk W, Galas W (1999) Chemical characteristics of waters in the Hornsund region in the summer of 1998. Polish Polar Studies, In: Proceedings of XVIth Polar Symposium. Lublin, pp 243-250

Standard Methods for examination of water and wastewater (1999) Am Publ Health 554 ASN, New York
Stibal M, Tranter M, Benning LG, Rehák J (2008) Microbial primary production on an Arctic glacier is insignificant in comparison with allochthonous organic carbon input. Environ Microbiol 10:2172-2178

Vincent WF, Pienitz R, Laurion I, Walter AK (2013) Climate impacts on Arctic lakes. In: Goldman CR, Kumagai M, Robarts RD (eds) Climatic change and global warming of inland waters: impacts and mitigation for ecosystems and societies. Wiley, Chichester, pp 27-42

Zdanowski MK, Żmuda-Baranowska MJ, Borsuk P, Świątecki A, Górniak D, Wolicka D, Jankowska KM, Grzesiak J (2013) Culturable bacteria community development in postglacial soils of Ecology Glacier, King George Island, Antarctica. Polar Biol 36:511-527

Zuber A (ed) (2007) Tracer methods in hydrogeological studies. Oficyna Wydawnicza Politechniki Wrocławskiej, Wrocław (in Polish) 